\title{
Hydrophilic poly-ether side-chained benzodithiophene-based homopolymer for solar cells and field-effect transistors
}

\author{
Qian Liu $\cdot$ Xichang Bao $\cdot$ Yan Yan · \\ Zhengkun Du • V. A. L. Roy • Dangqiang Zhu • \\ Mingliang Sun · Chun Sing Lee · Renqiang Yang
}

Received: 27 October 2014/Accepted: 12 December 2014/Published online: 24 December 2014

(c) Springer Science+Business Media New York 2014

\begin{abstract}
Two benzodithiophene (BDT)-based homopolymers which have different mole ratios of poly-ether side chain substitute were synthesized by Stille coupling reaction. The polymers show decomposition temperature $\left(T_{\mathrm{d}}\right)$ around $317^{\circ} \mathrm{C}$ and optical band gap around $2.2 \mathrm{eV}$. Solar cell devices with bulk heterojunction structure and field-effect transistors devices were fabricated to evaluate the photovoltaic properties of resultant polymers. Solar cell devices based on the polymer with $100 \%$ poly-ether side chain (P1) show low power conversion efficiencies (PCEs) of $0.71 \%$ resulting from the poor morphology of active layer which has rough surface and fairly large domain size due to the high aggregation tendency of P1:PCBM $([6,6]-$ phenyl-C61-butyric acid methyl ester) blend thin film as active layer in the structure of devices. Polymer with alternating poly-ether and alkoxy chained BDT (P2) and PCBM blend film shows smooth surface and appropriate domain size, which help to enhance the hole transportation and photovoltaic performances. The PCEs of the devices
\end{abstract}

Q. Liu $\cdot$ X. Bao $\cdot$ Z. Du $\cdot$ D. Zhu $\cdot$ R. Yang $(\bowtie)$

CAS Key Laboratory of Bio-based Materials, Qingdao Institute of Bioenergy and Bioprocess Technology, Chinese Academy of Sciences, Qingdao 266101, Shandong, China

e-mail: yangrq@qibebt.ac.cn

Q. Liu $\cdot$ M. Sun $(\bowtie)$

Institute of Materials Science and Engineering, Ocean University of China, Qingdao 266100, Shandong, China

e-mail: mlsun@ouc.edu.cn

Y. Yan · V. A. L. Roy · M. Sun · C. S. Lee

Center of Super-Diamond and Advanced Films (COSDAF), City

University of Hong Kong, Kowloon Tong, Hong Kong

M. Sun

Shenzhen Research Institute, City University of Hong Kong,

High-Tech Zone, Nanshan District, Shenzhen, China based on P2 reached $2.00 \%$ which is a decent result for BDT-based homopolymer donor with relatively large band gap (ca. $2.2 \mathrm{eV}$ ). These two polymers exhibited mobilities of $3.95 \times 10^{-4}$ and $6.18 \times 10^{-4} \mathrm{~cm}^{2} / \mathrm{Vs}$ in field-effect transistors, respectively.

\section{Introduction}

Bulk heterojunction (BHJ) polymer solar cells (PSCs) based on $\pi$-conjugated (semiconducting) polymers and fullerene derivatives have attracted much attention as a promising candidate for clean and renewable solar energy conversion technologies because of their advantages, such as low cost, flexibility, and solution processing [1-6]. During the past decades, tremendous efforts have been devoted to develop novel conjugated polymers with different alternating units along the polymer backbone, and the power conversion efficiencies (PCEs) of PSCs based on these polymers have been improved from about $1 \%$ to more than $9 \%$ [7-12]. For example, donor-acceptor conjugated polymers with alternating electron-rich (donor) and electron-deficient (acceptor) units can achieve appropriate band gap and energy level by controlling the intramolecular charge transfer (ICT) from donor to acceptor moieties. This kind of polymers can achieve relatively high photovoltaic performance [8]. However, some recent studies have begun to focus on the effect of different side chains on conjugated polymers with the same backbone sequence. Although the side chains have minimal impact on the observed band gap and energy levels of the polymer, appropriate side chains can improve the polymer solubility, molecular weight, mobility, $\pi-\pi$ stacking, and the morphology of phase-separated blends which definitely will affect the device efficiencies [13-16]. 
Andersson and Hou reported fluorene and dithien-2-yl2,1,3-benzothiadiazole (DTBT)-based polymers (PFDTBT) which have identical polymer backbone but different alkyl side chains. The relationship between side chain bulkiness and the measured PCEs was exposed. PFDTBT with ethylhexyl and hexyl substitutes on fluorene unit exhibited PCE of $2.2 \%$, while BisDMO-PF-DTBT with 3,7-dimethyl-octyl substitutes showed a higher PCE of $4.5 \%$ [17, 18]. The effects of side chain have also been systematically explored on one of the best polymer photovoltaic materials to date, P3HT [19-22]. Gadisa and coworkers studied the charge transport and photovoltaic characteristics of regioregular poly(3-alkyllthiophene) (P3AT), including P3BT, P3PT, and P3HT [20]. The authors proposed that the longer side chain facilitated the PCBM clusters formation by establishing efficient electronpercolation pathways. Essentially, balanced electron/hole mobilities were obtained with proper phase separation, leading to a high fill factor. In another study of functionalized side chains with different amounts in P3HT by Janssen et al. [9], the authors clearly demonstrated the possibility to tune the performances of (P3HT-based) conjugated polymer donor materials by introducing the functionalized side chains in moderate amounts, and they showed that functionalized P3AT copolymers, obtained via post-polymerization protocols from the presented esterfunctionalized P3ATs (affording alcohol and cinnamoyl moieties in the side chains), provide a considerably more stable active layer blend morphology upon prolonged thermal annealing compared to regular P3HT. In 2008, Hou and Yang reported primarily the synthesis and electronic properties of benzodithiophene (BDT)-based copolymers [23]. Since then, the BDT unit has become one of the most employed donor moieties for PSCs, and a variety of BDT-based copolymers with substantial PCEs of 5-8 \% were designed and synthesized [24-35]. Despite these features, the research of side chains on BDT-based polymers is still in its infancy and most of the limited studies are focused on copolymers [13, 14, 16, 36]. Compared with copolymers, homopolymers have more simple structure and are more suitable for considering the effects of side chains. For example, Ferraris et al. explored the effect of the dialkoxy and dithioalkoxy side chains on BDT unit by comparing the computational calculations and experimental results of O-BDT homopolymer, S-BDT homopolymer, and S-BDT-alt-O-BDT copolymer. The replacement of the alkoxy groups with thioalkoxy groups lowered the HOMO energy of the homopolymer from 5.31 to $-5.41 \mathrm{eV}$ and consequently enhanced open circuit voltage $\left(V_{\mathrm{oc}}\right)$ and ultimately the PCEs were improved from 1.56 to $4.00 \%$ which is comparable with PCBM and P3HT system (the best homopolymer solar cells donor) [37]. However, the dithioalkoxy side-chained BDT-based homopolymer exhibited low FF value of 0.53 which can be enhanced by forming more reliable morphology of polymer:PCBM blend [20].

In this paper, two BDT-based homopolymers with different mole ratios of poly-ether side chain were synthesized by Stille coupling reaction. Polymer solar cell devices were fabricated with BHJ structure with the synthesized polymers as donor and PCBM as acceptor. Our preliminary results show that it is an effective way to modulate the morphology of donor and acceptor blend film by controlling the mole percentage of hydrophilic poly-ether side chain in BDT-based homopolymer donor.

\section{Experimental section}

\section{Materials}

Unless otherwise stated, all reagents and starting materials were used as commercially purchased without further purification. All air- and water-sensitive reactions were performed under argon atmosphere. Toluene and tetrahydrofuran (THF) were distilled from sodium with benzophenone as indicator, and $\mathrm{N}, \mathrm{N}$-dimethylformamide (DMF) was distilled from $\mathrm{CaH}_{2}$ under argon atmosphere prior to use. Compounds 1 and 5 were synthesized according to the reported literature [23].

\section{Characterization}

${ }^{1} \mathrm{H}$ and ${ }^{13} \mathrm{C}$ NMR (Nuclear Magnetic Resonance) spectra were recorded on a Bruker Advance III600 (600 MHz) spectrometer. Thermogravimetric analysis (TGA) and differential scanning calorimetry (DSC) were conducted on TA-Q600 equipment. The Ultraviolet-Visible (UV-Vis) absorption spectra were recorded by Hitachi U-4100 spectrophotometer. Cyclic Voltammetry (CV) measurements were performed on a CHI660D electrochemical workstation. Atomic Force Microscope (AFM) images were acquired with Agilent-5400 scanning probe microscope with a Nanodrive controller in tapping mode with MikroMasch NSC-15 AFM tips with resonant frequencies $\sim 300 \mathrm{MHz}$. X-ray diffraction (XRD) spectra were recorded on a Bruker D8 Advance.

\section{Solar cell devices fabrication}

Photovoltaic devices were fabricated on $15 \times 15 \mathrm{~mm}^{2}$ indium-tin-oxide (ITO)-coated glass substrates with a layered structure of ITO/PEDOT:PSS/Polymer:PCBM/Ca/Al. The ITO-coated glass substrates were cleaned in an ultrasonic bath in ITO leaner, distilled water, acetone, distilled water, and isopropyl alcohol sequentially. The substrates 
were then oxygen plasma treated for $20 \mathrm{~min}$, spin coated with PEDOT:PSS at $4000 \mathrm{rpm}$, and dried under argon at $160{ }^{\circ} \mathrm{C}$ for $25 \mathrm{~min}$. The polymer and PCBM were dissolved in deoxygenated anhydrous chloroform in the weight ratios from 2:1, 1:1, 1:2 respectively and stirred overnight in MBraun glovebox. An active layer consisting of the blend of polymer and PCBM was then spin coated on PEDOT:PSS at $3000 \mathrm{rpm}$. Typical concentration of the polymer:PCBM blending solution was $24 \mathrm{mg} / \mathrm{mL}$ in this work. Subsequently, Ca $(10 \mathrm{~nm})$ and $\mathrm{Al}(100 \mathrm{~nm})$ were thermally evaporated at a vacuum of $\sim 2 \times 10^{-4} \mathrm{~Pa}$ on top of active layer as a cathode. Photovoltaic performance was characterized under illumination with an AM1.5 $(100 \mathrm{~mW} /$ $\left.\mathrm{cm}^{2}\right)$ in a nitrogen atmosphere $\left(<0.1 \mathrm{ppm} \mathrm{H}_{2} \mathrm{O}\right.$ and $\left.\mathrm{O}_{2}\right)$, and current voltage curve was recorded by Keithley 2420 .

Fabrication of field-effect transistors (FET) devices

Bottom-gate/top-contact transistors were fabricated on heavily $n$-doped silicon substrates (served as gate electrode) with $100 \mathrm{~nm}$ thermal oxide $\left(\mathrm{SiO}_{2}\right)$ layers. After standard cleaning (15 min ultrasonic process in acetone, isopropanol and DI-water, sequentially), $5 \mathrm{mg} / \mathrm{mL}$ polymer dissolved in chloroform were spin coated on $\mathrm{SiO}_{2}$ substrates at a speed of $1200 \mathrm{rpm}$ for $1 \mathrm{~min}$. Then, substrates were annealed on a hot plate at $120^{\circ} \mathrm{C}$ for $30 \mathrm{~min}$. Afterward, a 100-nm-thick gold film was vacuum sublimed as source/drain electrodes on semiconductor surface through a shadow mask (channel length/width $=50$ / $1000 \mu \mathrm{m})$ at a rate of $0.2 \AA / \mathrm{s}$.

Synthesis of monomers and polymers

\section{Synthesis of E-BDT (compound 2)}

Under the protection of argon, benzo[1,2-b:4,5-b']dithiophen-4,8-dione (compound 1, $1.1 \mathrm{~g}, 5 \mathrm{mmol}$ ), zinc power (719 mg, $11 \mathrm{mmol}$ ), and $20 \mathrm{~mL}$ of distilled water were put into a $100 \mathrm{~mL}$ flask; then $\mathrm{NaOH}(3 \mathrm{~g}, 75 \mathrm{mmol})$ was added into the mixture. The mixture was stirred and heated to reflux for $1 \mathrm{~h}$. During the reaction, the color of the mixture changed from yellow to red and then to origin. Subsequently, 1-(2-ethoxyethoxy)-2-bromoethane (2.96 g, $15 \mathrm{mmol})$ and a catalytic amount of tetrabutylammonium bromide $(161 \mathrm{mg}, 0.5 \mathrm{mmol})$ were added into the flask. After being refluxed for $6 \mathrm{~h}$, the reactant was poured into cold water and extracted with diethyl ether. The ether layer was dried over by anhydrous $\mathrm{MgSO}_{4}$. After removing the solvent, the crude product was purified by column chromatography using petroleum and acetic ether $(2: 1)$ as the eluent and then recrystallized from ethyl alcohol. E-BDT (compound 2) was obtained as a colorless crystal (1.89 g, yield $83 \%)$. ${ }^{1} \mathrm{H}$ NMR $\left(\mathrm{CDCl}_{3}, 600 \mathrm{MHz}\right), \delta(\mathrm{ppm}): 7.58$ $(\mathrm{d}, J=5.4 \mathrm{~Hz}, 2 \mathrm{H}), 7.36(\mathrm{~d}, J=5.4 \mathrm{~Hz}, 2 \mathrm{H}), 4.44(\mathrm{~m}$, $4 \mathrm{H}), 3.88(\mathrm{~m}, 4 \mathrm{H}), 3.75(\mathrm{~m}, 4 \mathrm{H}), 3.65(\mathrm{~m}, 4 \mathrm{H}), 3.56(\mathrm{~m}$, $4 \mathrm{H}), 1.23(\mathrm{t}, J=6.6 \mathrm{~Hz}, J=7.2 \mathrm{~Hz}, 6 \mathrm{H})$.

\section{Synthesis of E-BDT-Br (compound 3)}

Under the protection of argon, compound 2 (1.82 g, $4 \mathrm{mmol}$ ) and $50 \mathrm{~mL}$ of THF were added into a $100 \mathrm{~mL}$ flask. The solution was cooled down to $-78{ }^{\circ} \mathrm{C}$ and $5.5 \mathrm{~mL}$ of $n$-butyllithium ( $8.8 \mathrm{mmol}, 1.6 \mathrm{M}$ in $n$-hexane) was added dropwise. After being stirred at $-78^{\circ} \mathrm{C}$ for $2 \mathrm{~h}$, a great deal of white solid precipitate appeared in the flask. Then, carbon tetrabromide $(3.05 \mathrm{~g}, 9.2 \mathrm{mmol})$ was added in one portion and the reactant turned black but clear rapidly. Then the reactant was stirred at ambient temperature for another $2 \mathrm{~h}$. Then, it was poured into $100 \mathrm{~mL}$ of cool water and extracted with diethyl ether. The organic layer was washed by water and dried by anhydrous $\mathrm{MgSO}_{4}$. After removing the solvent under vacuum, the residue was purified by column chromatography using petroleum ether and acetic ether (2:1) as eluent and recrystallized from ethyl alcohol. $1.37 \mathrm{~g}$ of E-BDT-Br (compound 3) was obtained as a colorless needle crystal $(2.24 \mathrm{mmol}$, yield $56 \%) .{ }^{1} \mathrm{H}$ NMR $\left(\mathrm{CDCl}_{3}, 600 \mathrm{MHz}\right) \delta(\mathrm{ppm}): 7.56(\mathrm{~s}, 2 \mathrm{H})$, $4.35(\mathrm{~m}, 4 \mathrm{H}), 3.84(\mathrm{~m}, 4 \mathrm{H}), 3.74(\mathrm{~m}, 4 \mathrm{H}), 3.66(\mathrm{~m}, 4 \mathrm{H})$, $3.58(\mathrm{~m}, 4 \mathrm{H}), 1.24(\mathrm{t}, J=6.6 \mathrm{~Hz}, J=7.2 \mathrm{~Hz}, 6 \mathrm{H}) .{ }^{13} \mathrm{C}$ NMR $\left(\mathrm{CDCl}_{3}, 151 \mathrm{MHz}\right), \delta(\mathrm{ppm}): 142.4,131.4,131.2$, $123.4,115.1,73.1,71.0,70.3,69.9,66.8,15.2$.

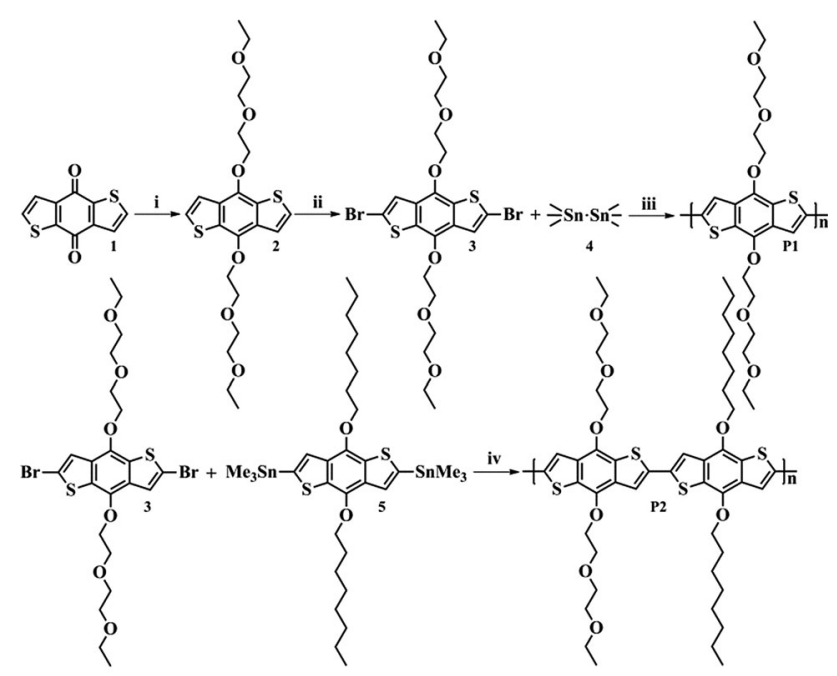

(i) $\mathrm{Zn}$, $\mathrm{NaOH}, \mathrm{H}_{2} \mathrm{O}$, reflux for 1h; then 1-(2-ethoxyethoxy)-2-bromoethane, TBAB, reflux for 6h. (ii) n-butyllithium, THF, $-78^{\circ} \mathrm{C}$, 1h, argon; then $\mathrm{CBr}_{4}$, ambient temperature, $2 \mathrm{~h}$, argon. (iii-iv) $\mathrm{Pd}_{2}(\mathrm{dba})_{3}, \mathrm{P}\left(o-\mathrm{Tol}_{3}\right)$, Toluene and $\mathrm{DMF}, 100^{\circ} \mathrm{C}, 12 \mathrm{~h}$.

Scheme 1 Synthetic routes of P1 and P2 
Synthesis of polymers $(P 1, P 2)$

The two polymers (P1 and P2 in Scheme 1) were prepared with the same procedure of coupling dibromide compounds with bis-(trimethylstannyl)-substituted compounds.

$0.5 \mathrm{mmol}$ of dibromide compound, $0.5 \mathrm{mmol}$ of bis(trimethylstannyl)-substituted compound, $8 \mathrm{~mL}$ of toluene, and $2 \mathrm{~mL}$ of DMF were put into a two-necked flask. The mixture was purged with argon for $30 \mathrm{~min}$, then $\mathrm{Pd}_{2}(\mathrm{dba})_{3}(10 \mathrm{mg})$, and $\mathrm{P}(o-\mathrm{Tol})_{3}(20 \mathrm{mg})$ were added, then the reaction was heated to $100{ }^{\circ} \mathrm{C}$ and stirred for $12 \mathrm{~h}$ under argon atmosphere. The mixture was cooled down to ambient temperature and the polymer was precipitated by addition of $150 \mathrm{~mL}$ methanol and filtered through a Soxhlet thimble, which was then subjected to Soxhlet extraction with methanol, hexane, and chloroform. The polymer was recovered as a solid sample from the chloroform fraction by rotary evaporation. The solid was dried under vacuum for 1 day to get the final product. The yields of the polymerization reactions were $79 \%$ for $\mathrm{P} 1$ and $83 \%$ for P2. P1: ${ }^{1} \mathrm{H}$ NMR $\left(\mathrm{CDCl}_{3}, 600 \mathrm{MHz}\right), \delta$ (ppm): 7.75-7.29 (br, 2H), 4.54-3.63 (br, 20H), 1.28 (br, 6H). P2: ${ }^{1} \mathrm{H}$ NMR $\left(\mathrm{CDCl}_{3}, 600 \mathrm{MHz}\right), \delta$ (ppm): 7.54-7.26 (br, 4H), 4.64-3.50 (br, 24H), 2.00 (br,4H), 1.68-1.25 (br, 26H), 0.97 (br, 6H).

\section{Results and discussion}

\section{Synthesis and characterization}

The synthetic routes to the monomers and polymers are outlined in Scheme 1. Compound 1 was reduced by zinc dust in aqueous sodium hydroxide solution, when the reduction reaction was completed, 1-(2-ethoxyethoxy)-2-bromoethane was added with a catalytic amount of tetrabutylammonium bromide. After being refluxed for $12 \mathrm{~h}$, compound 2 was obtained. Compound 3 was achieved by the bromination of compound 2 with $n$-butyl lithium and $\mathrm{CBr}_{4}$. The polycondensation was carried out between organic tin compounds and bromides through the Stille coupling reaction. The monomers were characterized by ${ }^{1} \mathrm{H}$ NMR and ${ }^{13} \mathrm{C}$ NMR. The polymers were dissolved only in chloroform, so the gel permeation chromatography data were not given.

\section{Thermal stability}

The thermal behavior of the polymers was evaluated by TGA and DSC in nitrogen with a heating rate of $10^{\circ} \mathrm{C} /$ min. As depicted in Fig. 1, the two polymers showed good thermal stability. The $5 \%$ weight loss of the polymers took place at $318{ }^{\circ} \mathrm{C}$ for $\mathrm{P} 1$ and $316^{\circ} \mathrm{C}$ for $\mathrm{P} 2$. The good thermal stability of polymers prevents the deformation of

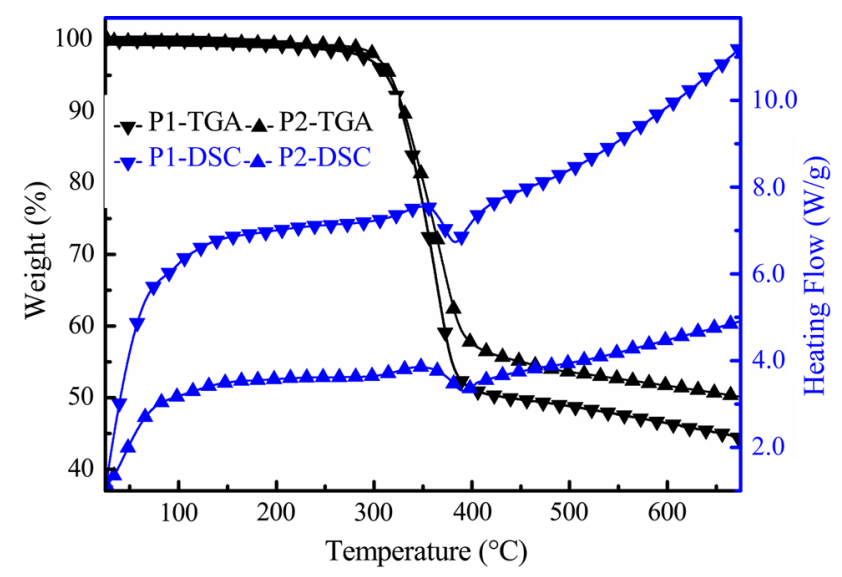

Fig. 1 TGA and DSC curves of P1 and P2

the polymer morphology and the degradation of the polymeric active layer under applied electric field in the solar cell devices. The polymers show no glass transition in DSC characterization during the scanning range from 30 to $350{ }^{\circ} \mathrm{C}$ at the rate of $10{ }^{\circ} \mathrm{C} / \mathrm{min}$ under nitrogen flow. The thermal data are summarized in Table 1.

\section{Optical properties}

The optical absorption spectra of the polymers $\mathrm{P} 1$ and $\mathrm{P} 2$ in chloroform solution and in spin-coated thin films are shown in Fig. 2, and the corresponding absorption properties are summarized in Table 1. The polymers showed similar absorption profiles with two peaks from 400 to $600 \mathrm{~nm}$, which should be ascribed to the $\pi-\pi$ transitions in the polymer backbone. The absorption maxima of $\mathrm{P} 1$ and $\mathrm{P} 2$ in solution occurred at 520/486 and 524/485 nm respectively, whereas those in the thin films occurred at 536/497 and $536 / 494 \mathrm{~nm}$. Obviously, the absorption spectra of the polymer films were red-shifted compared to those in solution, indicating the gain of planarity of the polymers and the strong interaction between polymer chains in the film states. The onsets of solid film absorption of P1 and P2 occurred at 566 and $560 \mathrm{~nm}$. The onset absorption wavelength of $\mathrm{P} 1$ is higher than $\mathrm{P} 2$ which indicated that the efficient conjugation length of P1 was bigger than P2. This was consistent with the assumption that poly-ether side chains did not cause a detrimental steric twist of the polymer out of planarity which would be beneficial for the $\pi-\pi$ stacking [38].

The optical band gaps $\left(E_{\mathrm{g}}^{\mathrm{opt}}\right)$ deduced from the onset of absorption in the solid state are determined to be $2.19 \mathrm{eV}$ for P1 and $2.21 \mathrm{eV}$ for P2.

Electrochemical properties

To determine the highest occupied molecular orbital (HOMO) and the lowest unoccupied molecular orbital 
Table 1 Optical, electrochemical, and thermal properties of P1 and P2

\begin{tabular}{|c|c|c|c|c|c|c|c|}
\hline Polymer & $\lambda_{\max }$ sol $(\mathrm{nm})$ & $\lambda_{\max }$ film $(\mathrm{nm})$ & $\lambda_{\text {onset }}$ film $(\mathrm{nm})$ & $E_{\mathrm{g}}^{\mathrm{opt}}(\mathrm{eV})$ & $E_{\text {onset }}^{\text {ox }}(\mathrm{V})$ & HOMO (eV) & $T_{\mathrm{d}}\left({ }^{\circ} \mathrm{C}\right)$ \\
\hline $\mathrm{P} 1$ & $520 ; 486$ & $536 ; 497$ & 566 & 2.19 & 0.75 & -5.11 & 318 \\
\hline $\mathrm{P} 2$ & $524 ; 485$ & $536 ; 494$ & 560 & 2.21 & 0.82 & -5.18 & 316 \\
\hline
\end{tabular}

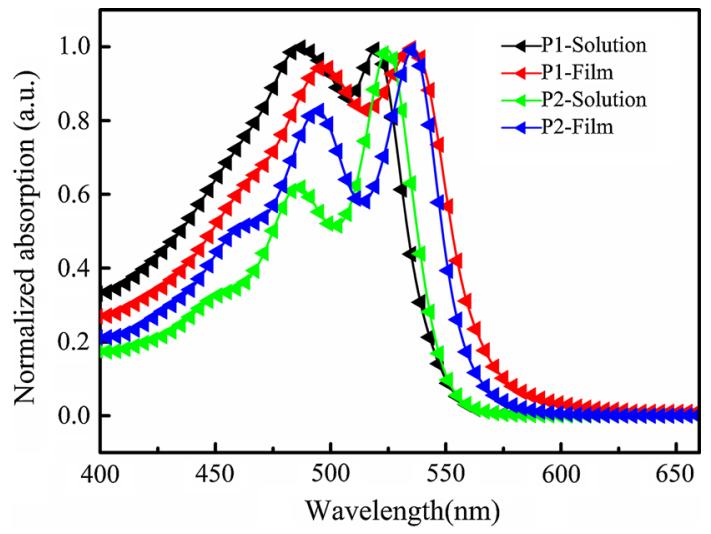

Fig. 2 Normalized UV-Vis absorption spectra of P1 and P2 in solution and thin film

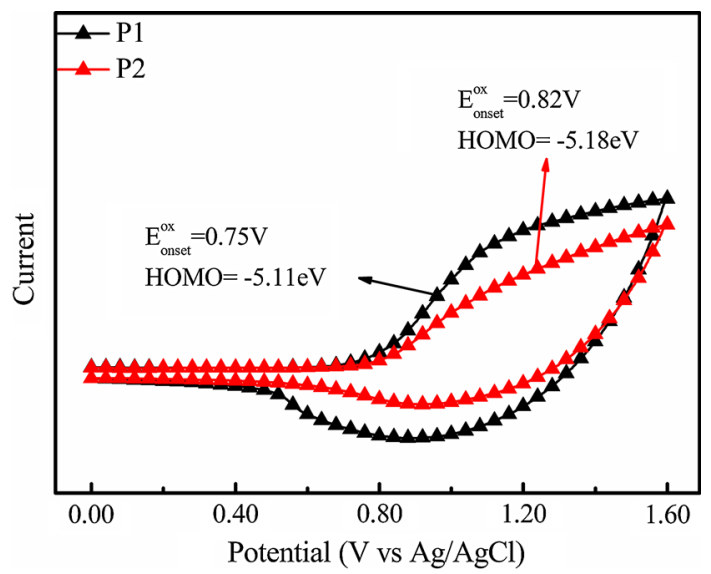

Fig. 3 Cyclic voltammograms of P1 and P2

(LUMO) energy levels, we investigated the electrochemical properties of the polymers by CV. A glassy carbon, modified with a polymer film by means of dip-coating, was used as the working electrode, whereas a platinum wire was used as the counter electrode and $\mathrm{Ag} / \mathrm{AgCl}$ served as the reference electrode. $\mathrm{CV}$ were carried out in $\mathrm{Bu}_{4} \mathrm{NPF}_{6}$ $(0.1 \mathrm{M})$ /acetonitrile electrolyte at room temperature under a nitrogen atmosphere at a scan rate of $50 \mathrm{mV} / \mathrm{s}$. The $\mathrm{CV}$ plots of P1 and P2 are shown in Fig. 3, and the electrochemical properties are summarized in Table 1. The HOMO energy level of the polymers can be deduced from the oxidation onsets, assuming that the energy level of ferrocene $(F \mathrm{c})$ is $4.8 \mathrm{eV}$ below the vacuum level [39]. The redox potential of $F \mathrm{c} / \mathrm{Fc}^{+}$internal reference vs. $\mathrm{Ag} / \mathrm{AgCl}$ is $0.44 \mathrm{~V}$, and the onset of oxidation for P1 and P2 occurred at 0.75 and $0.82 \mathrm{~V}$ in the same conditions, which corresponds to HOMO values of -5.11 and $-5.18 \mathrm{eV}$, respectively. The LUMO levels of P1 and P2 were calculated from the optical band gaps and HOMO energy levels to be -2.92 and $-2.97 \mathrm{eV}$.

Polymer solar cell performance

To elucidate the relationship between the conjugated polymers molecular structure and the solar cell devices performance, BHJ-type PSCs (ITO/PEDOT:PSS/active layer $/ \mathrm{Ca} / \mathrm{Al}$ ) were fabricated based on the blends of $\mathrm{P} 1$ and P2 with PCBM. Figure 4a, b show the current density vs. voltage $(J-V)$ curves under AM 1.5 illumination at $100 \mathrm{~mW} / \mathrm{cm}^{2}$. The representative characteristics of the PSCs devices are summarized in Table 2. In order to obtain optimized device performance, different weight ratios (2:1, 1:1, 1:2) of P1 or P2: PCBM were used. As shown in Fig. 4 and Table 2, the best device performance was obtained in a 1:1 polymer: PCBM weight ratio spin-cast from chloroform with $V \mathrm{oc}=0.68 \mathrm{~V}, \quad J \mathrm{sc}=2.06 \mathrm{~mA} / \mathrm{cm}^{2}, \quad \mathrm{FF}=$ $50.55 \%, \quad \mathrm{PCE}=0.71 \%$ for $\mathrm{P} 1$ and $V \mathrm{Oc}=0.68 \mathrm{~V}$, $J \mathrm{sc}=4.86 \mathrm{~mA} / \mathrm{cm}^{2}, \mathrm{FF}=60.46 \%, \mathrm{PCE}=2.00 \%$ for $\mathrm{P} 2$. For comparison, a published homopolymer containing alkoxy side chain only was founded [37], and the photovoltaic parameters are $V \mathrm{oc}=0.83 \mathrm{~V}, J \mathrm{sc}=4.18 \mathrm{~mA} / \mathrm{cm}^{2}$, $\mathrm{FF}=45 \%$, and $\mathrm{PCE}=1.56 \%$. From the characterized data, it is almost certain that the oxygen atom plays a crucial role to the photovoltaic properties and an optimal ratio of poly-ether side chain existed.

The external quantum efficiency (EQE) curves of the devices based on P1/PCBM and P2/PCBM (1:1, w/w) prepared under optimized conditions are shown in Fig. 4c. Both the devices exhibited photoresponse range from 300 to $600 \mathrm{~nm}$, with the maximum EQE of $21.4 \%$ for P1 and $61.5 \%$ for P2. To confirm the accuracy of the photovoltaic measurements, the $J \mathrm{sc}\left(2.03 \mathrm{~mA} / \mathrm{cm}^{2}\right.$ for $\mathrm{P} 1$ and $4.81 \mathrm{~mA} /$ $\mathrm{cm}^{2}$ for P2) were calculated from integration of the EQE curves, which agree well with the $J \mathrm{sc}\left(2.06 \mathrm{~mA} / \mathrm{cm}^{2}\right.$ for $\mathrm{P} 1$ and $4.86 \mathrm{~mA} / \mathrm{cm}^{2}$ for P2) obtained from the $J-V$ measurements. 
Fig. 4 a, b $J-V$ curves of $\mathrm{P} 1$ and P2/PCBM-based solar cells with different ratios. $\mathbf{c}$ EQE curves of P1 and P2/PCBM $(1: 1, w / w)$-based solar cells. d $J-V$ characteristics of $\mathrm{P} 1$ and P2/PCBM (1:1, w/w) hole-only devices measured at ambient temperature
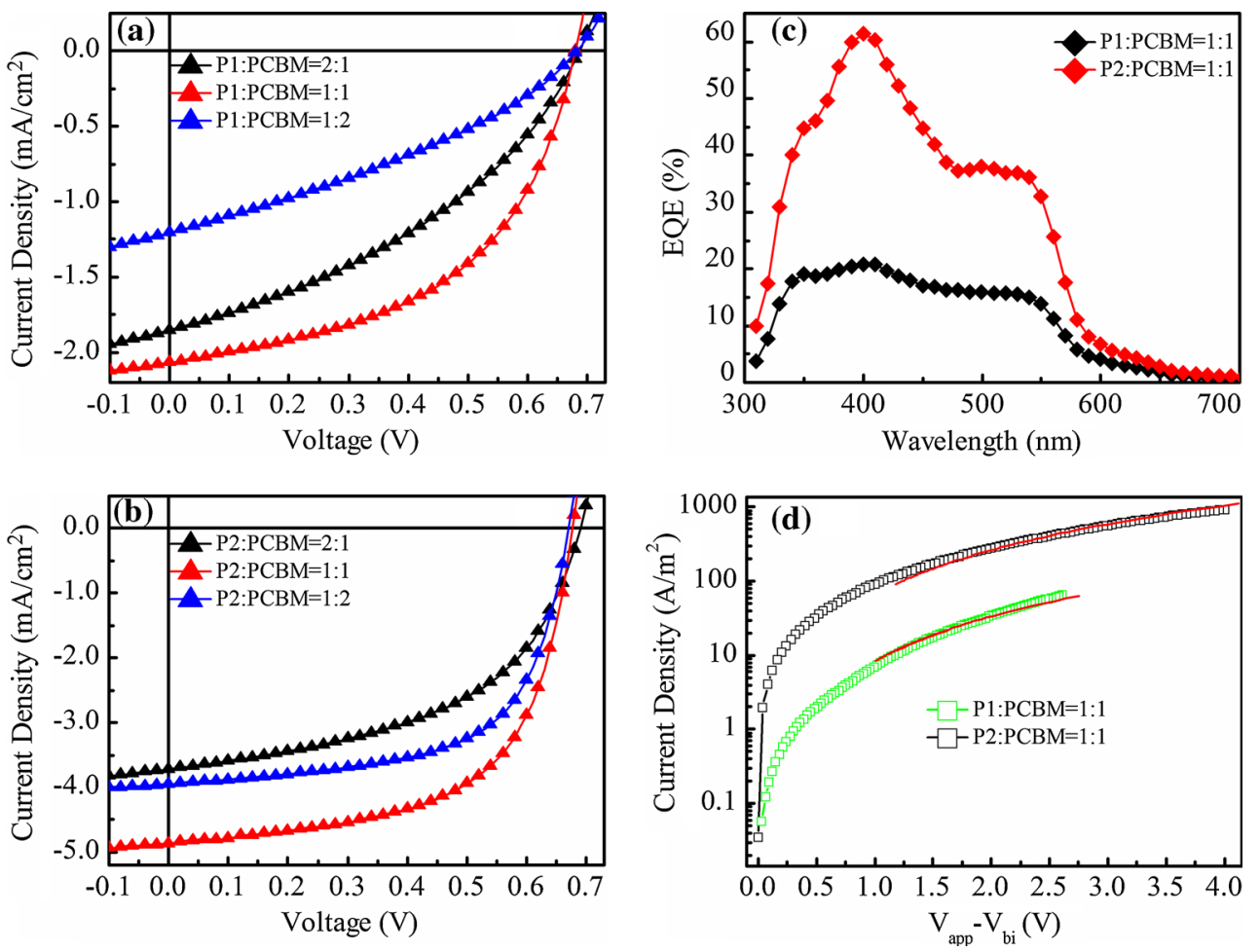

Table 2 Photovoltaic characteristics of $\mathrm{P} 1, \mathrm{P} 2$, and PCBM with different ratios

\begin{tabular}{llllll}
\hline Polymers & Ratios (D:A) & Voc $(\mathrm{V})$ & $J_{\mathrm{Sc}}\left(\mathrm{mA} / \mathrm{cm}^{2}\right)$ & FF $(\%)$ & PCE $(\%)$ \\
\hline P1 & $2: 1$ & 0.68 & 1.85 & 38.58 & 0.49 \\
& $1: 1$ & 0.68 & 2.06 & 50.55 & 0.71 \\
P2 & $1: 2$ & 0.68 & 1.20 & 33.98 & 0.28 \\
& $2: 1$ & 0.69 & 3.71 & 50.95 & 1.30 \\
& $1: 1$ & 0.68 & 4.86 & 60.46 & 2.00 \\
& $1: 2$ & 0.67 & 3.78 & 57.39 & 1.46 \\
\hline
\end{tabular}

To further study the performance of the PSCs devices, the hole mobilities in the photosensitive layers were measured by the space-charge limited current (SCLC) method and the plots are shown in Fig. 4d. Hole-only devices were constructed with the structure of ITO/PEDOT:PSS/polymer:PCBM/ $/ \mathrm{MoO}_{3} / \mathrm{Ag}$, and hole mobilities were calculated using the Mott-Gurney equation. For films of P1/PCBM and P2/PCBM, the SCLC mobilities were $3.69 \times 10^{-6}$ and $2.92 \times 10^{-5} \mathrm{~cm}^{2} / \mathrm{Vs}$, respectively. The higher hole mobility of P2 guaranteed the increased FF than P1.

X-ray diffraction and atomic force microscopy (AFM)

As the morphology of phase-separated blends are key issues to enhance the devices efficiency, XRD patterns and AFM images of P1/PCBM (1:1, w/w) and P2/PCBM (1:1, $w / w)$ blend films on ITO glass were carried out. The XRD patterns are shown in Fig. 5. P1 exhibited better crystallization capability with two peaks $\left(2 \theta=5.43^{\circ}\right.$ and
$2 \theta=21.20^{\circ}$ ) compared with $\mathrm{P} 2$, which is probably caused by the higher mole ratio of poly-ether of P1 [40]. Those peaks after $25^{\circ}$ correspond to the ITO substrate. However,

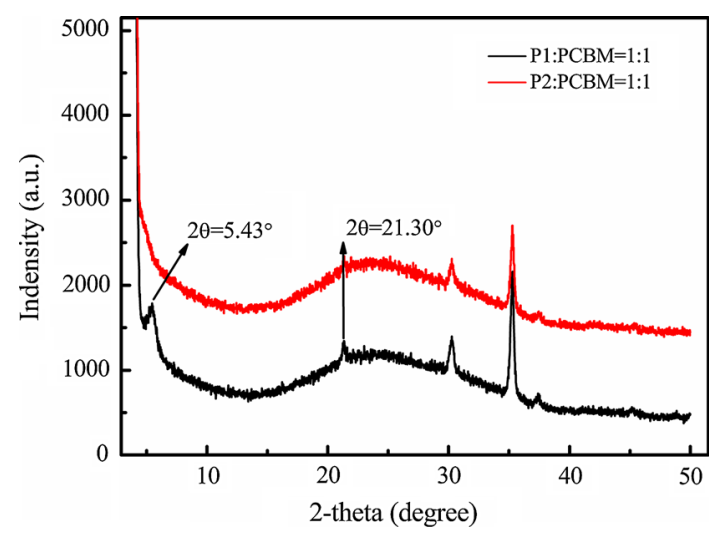

Fig. 5 X-ray diffraction patterns of P1:PCBM (1:1, w/w) and P2:PCBM $(1: 1, w / w)$ 
better crystallization may lead to rather rough surface and fairly large domain size, which is unfavorable to charge separation and consequently limits device performance.

The surface morphologies of P1/PCBM and P2/PCBM blend films $(1: 1, w / w)$ are measured by AFM. As shown in Fig. 6, P1/PCBM blend film exhibits rather rough surface with a RMS value of $5.01 \mathrm{~nm}$ and fairly large domain size over $100 \mathrm{~nm}$, which is unfavorable to charge separation and consequently limits device performance, so the best device based on P1 exhibited low $J \mathrm{sc}$ of $2.06 \mathrm{~mA} / \mathrm{cm}^{2}$ and PCEs of $0.71 \%$. Nevertheless, for P2 with combining alkoxy and poly-ether chains, relatively smooth blend film surface along with appropriate domain size $(20-40 \mathrm{~nm})$ are realized with RMS value of $2.54 \mathrm{~nm}$, indicating better nanoscale separation between the polymer and PCBM and more efficient percolation pathways that can facilitate charge transport to the respective electrodes and thereby lead to better performance. The best device based on P2 showed a PCE of $2.00 \%$.

Thin film field-effect transistors

The transfer characteristics curves of FETs based on P1 and $\mathrm{P} 2$ are shown in Fig. 7. The field-effect mobility $(\mu)$ was obtained by plotting $I_{\mathrm{DS}}^{1 / 2}$ vs. $V_{\mathrm{GS}}$ in the saturation regime $(-40 \mathrm{~V})$, using the equation

$\mu=\frac{2 \mathrm{~L}}{W C_{\mathrm{i}}}\left[\frac{I_{\mathrm{DS}}}{\left(V_{\mathrm{GS}}-V_{\mathrm{T}}\right)^{2}}\right]$,

where $I_{\mathrm{DS}}$ is the source-drain current, $W$ is the channel width, $L$ is the channel length, $C i$ is the capacitance of the dielectric, $V_{\mathrm{GS}}$ is the gate voltage, and $V_{\mathrm{T}}$ is the threshold voltage. The polymer P1 had mobility of $3.95 \times 10^{-4} \mathrm{~cm}^{2} /$ Vs, and the polymer P2 had a mobility of $6.18 \times 10^{-4}$ $\mathrm{cm}^{2} / \mathrm{Vs}$. P2 based FET devices show higher hole mobility than P1 device which agree with the SCLC results.

\section{Solar cells stability}

The stability of the best device based on P2 and PCBM blend was investigated. To simulate the encapsulated additions, the unencapsulated device was stored 16 days in nitrogen atmosphere under ambient temperature, and the changes of the photovoltaic parameters are shown in Fig. 8. As seen from Fig. 8, the Voc drops about $1 \%$, Jsc drops $2.6 \%$, FF drops $3.0 \%$, and PCE drops $5.5 \%$ after 16 days. These results demonstrated that the devices based
Fig. 6 AFM topography $(\mathbf{a}, \mathbf{b})$ and phase images $(\mathbf{c}$, d) of P1/PCBM $(1: 1, w / w)$ blend film (a, c) and P2/PCBM $(1: 1, w / w)$ blend film $(\mathbf{b}, \mathbf{d})$
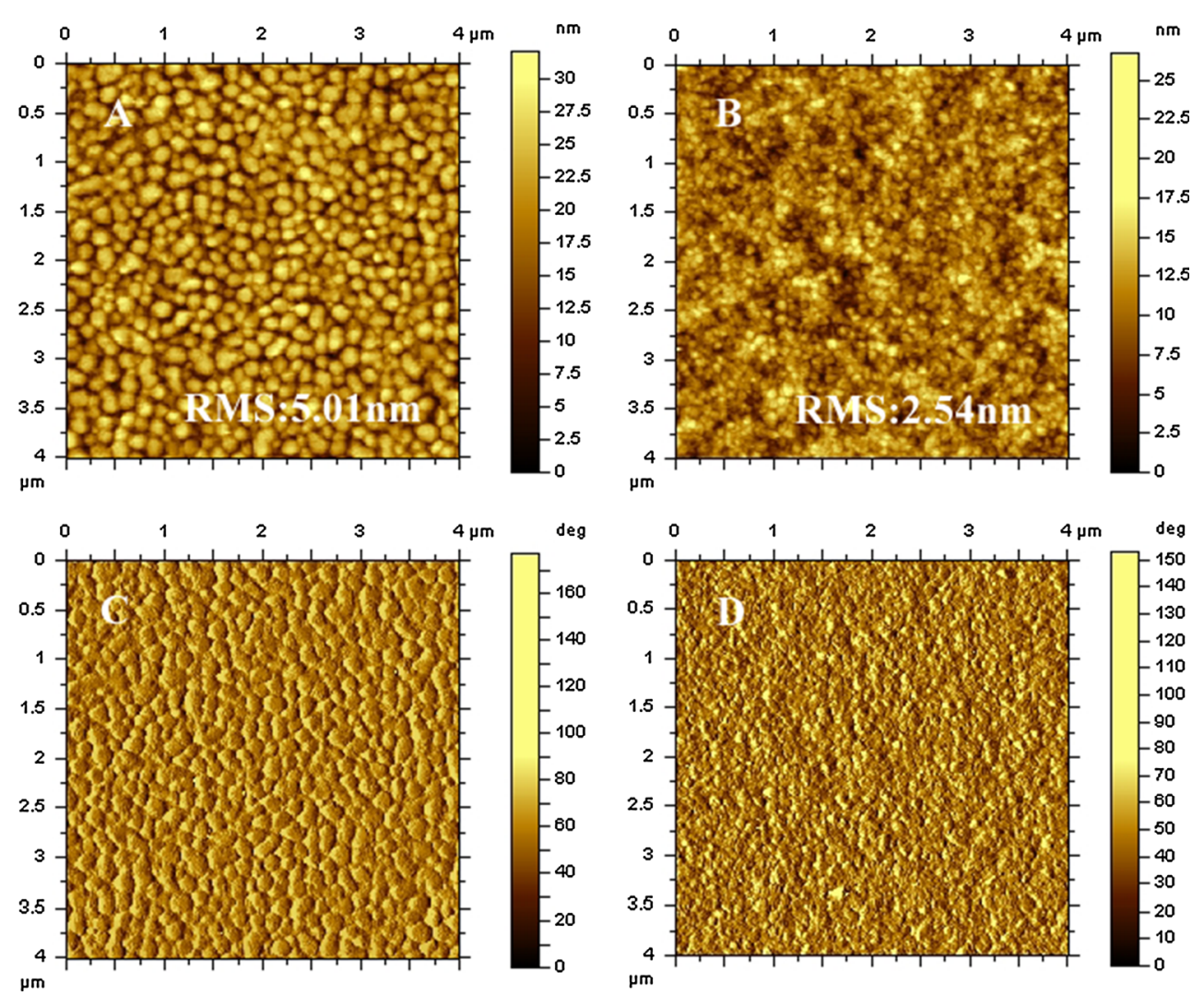

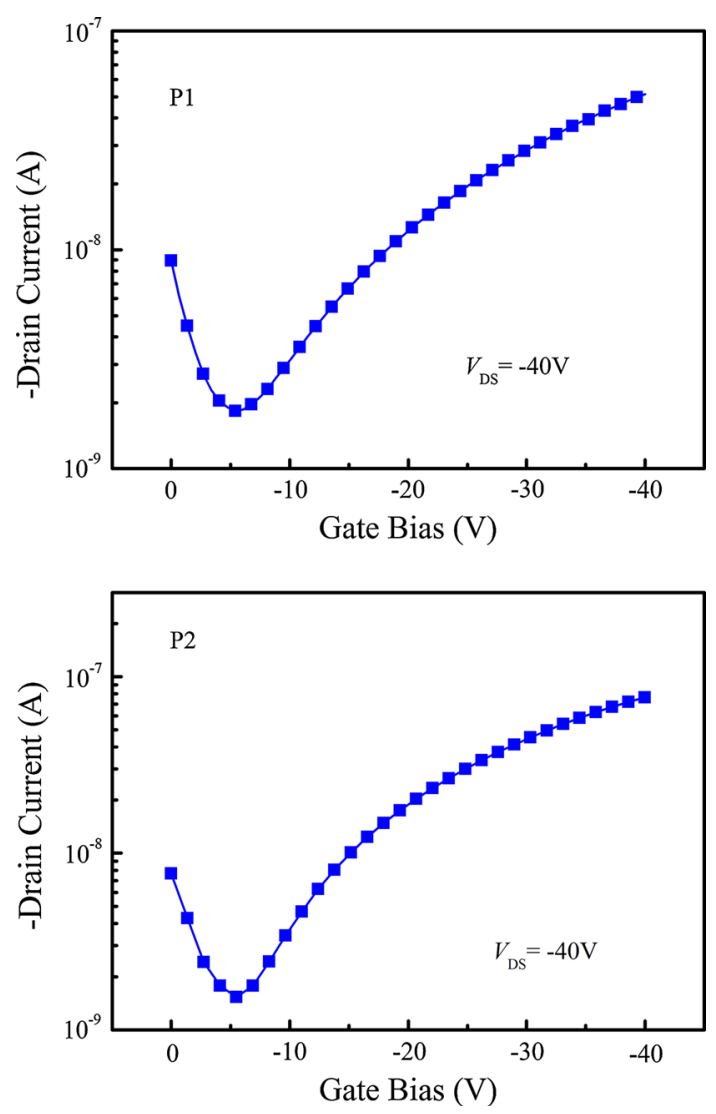

Fig. $7 I_{\mathrm{D}}$ vs. $V_{\mathrm{G}}$ transfer characteristics of P1- and P2-based FET devices

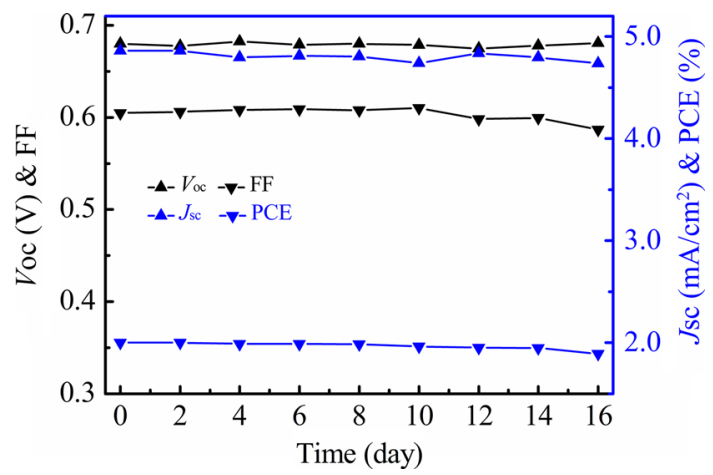

Fig. 8 Extract of the cell parameters up to 16 days aging for $\mathrm{P} 2: \mathrm{PCBM}(1: 1, \mathrm{w} / \mathrm{w})$ solar cell in nitrogen atmosphere

on P2 and PCBM would show good stability if they are well encapsulated.

\section{Conclusions}

In this paper, two BDT homopolymers with different mole ratios of poly-ether side chain were synthesized by Stille coupling reaction. Polymer with $100 \%$ poly-ether side chain (P1)-based solar cells show low PCEs of $0.71 \%$ resulting from rough surface and fairly large domain size due to the high aggregation tendency of P1:PCBM thin film. Polymer with alternating poly-ether and alkoxy chained BDT (P2) and PCBM blend film shows smooth surface and appropriate domain size, which help to the hole transportation and photovoltaic performances. The PCEs of the devices based on $\mathrm{P} 2$ reached $2.00 \%$ which is an acceptable result for a polymer donor with relatively high band gap (ca. $2.2 \mathrm{eV}$ ). Our preliminary results show that it is an effective way to modulate the morphology of donor and acceptor blend film by controlling the mole percentage of hydrophilic poly-ether side chain in polymer donor.

Acknowledgements The authors are deeply grateful to the National Natural Science Foundation of China (Project Nos. 21274134, 51173199, 61107090), New Century Excellent Talents in University (NCET-11-0473), Shandong Provincial Natural Science Foundation (ZR2011BZ007), Qingdao Municipal Science and Technology Program (11-2-4-22-hz, 13-1-4-200-jch) and Shenzhen Municipal Science and Technology Program (JCYJ20130401145617279) for financial support.

\section{References}

1. Yu G, Gao J, Hummelen JC, Wudl F, Heeger AJ (1995) Polymer photovoltaic cells: enhanced efficiencies via a network of internal donor-acceptor heterojunctions. Science 270:1789-1790

2. Brabec CJ (2004) Organic photovoltaics: technology and market. Sol Energy Mater Sol Cells 83:273-292

3. Günes S, Neugebauer H, Sariciftci NS (2007) Conjugated polymer-based organic solar cells. Chem Rev 107:1324-1338

4. Thompson BC, Fréchet JM (2008) Polymer-fullerene composite solar cells. Angew Chem Int Ed 47:58-77

5. Cheng YJ, Yang SH, Hsu CS (2009) Synthesis of conjugated polymers for organic solar cell applications. Chem Rev 109:5868-5923

6. Dennler G, Scharber MC, Brabec CJ (2009) Polymer-fullerene bulk-heterojunction solar cells. Adv Mater 21:1323-1338

7. Wen SG, Bao XC, Shen WF, Gu CT, Du ZK, Han LL, Zhu DQ, Yang RQ (2014) Benzodithiophene-based poly(aryleneethynylene)s: synthesis, optical properties, and applications in organic solar cell. J Polym Sci, Part A: Polym Chem 52:208-215

8. Liu Q, Bao XC, Wen SG, Du ZK, Han LL, Zhu DQ, Chen YH, Sun ML, Yang RQ (2014) Hyperconjugated side chained benzodithiophene and 4,7-di-2-thienyl-2,1,3-benzothiadiazole based polymer for solar cells. Polym Chem 5:2076-2082

9. Sista P, Kularatne RS, Mulholland ME, Wilson M, Holmes N, Zhou XJ, Dastoor PC, Belcher W, Rasmussen SC, Biewer MC, Stefan MC (2013) Synthesis and photovoltaic performance of donor-acceptor polymers containing benzo[1,2-b:4,5-b']dithiophene with thienyl substituents. J Polym Sci, Part A: Polym Chem 51:2622-2630

10. Zhang B, Yu L, Fan L, Wang N, Hu LW, Yang W (2014) Indolo[3,2-b]carbazole and benzofurazan based narrow band-gap polymers for photovoltaic cells. New J Chem 38:4587-4593

11. Tang WH, Hai JF, Shi GZ, Ma WL, Yu JS, Zhu EW, Bian LY (2014) Naphthodifuran alternating quinoxaline copolymers with a bandgap of $1.2 \mathrm{eV}$ and their photovoltaic characterization. New $\mathbf{J}$ Chem 38:4816-4822 
12. He ZC, Zhong CM, Su SJ, Xu M, Wu HB, Cao Y (2012) Enhanced power-conversion efficiency in polymer solar cells using an inverted device structure. Nat Photon 6:593-597

13. Szarko JM, Guo JC, Liang YY, Lee B, Rolczynski BS, Strzalka J, Xu T, Loser S, Marks TJ, Yu LP (2010) When function follows form: effects of donor copolymer side chains on film morphology and BHJ solar cell performance. Adv Mater 22:5468-5472

14. Piliego C, Holcombe TW, Douglas JD, Woo CH, Beaujuge PM, Fréchet JM (2010) Synthetic control of structural order in N-alkylthieno [3,4-c] pyrrole-4,6-dione-based polymers for efficient solar cells. J Am Chem Soc 132:7595-7597

15. Yang LY, Zhou HX, You W (2010) Quantitatively analyzing the influence of side chains on photovoltaic properties of polymerfullerene solar cells. J Phys Chem C 114:16793-16800

16. Zhou HX, Yang LY, Xiao SQ, Liu SB, You W (2009) Donoracceptor polymers incorporating alkylated dithienylbenzothiadiazole for bulk heterojunction solar cells: pronounced effect of positioning alkyl chains. Macromolecules 43:811-820

17. Svensson M, Zhang FL, Veenstra SC, Verhees WJ, Hummelen JC, Kroon JM, Inganäs O, Andersson MR (2003) High-performance polymer solar cells of an alternating polyfluorene copolymer and a fullerene derivative. Adv Mater 15:988-991

18. Chen MH, Hou JH, Hong ZR, Yang GW, Sista S, Chen LM, Yang Y (2009) Efficient polymer solar cells with thin active layers based on alternating polyfluorene copolymer/fullerene bulk heterojunctions. Adv Mater 21:4238-4242

19. Nguyen LH, Hoppe H, Erb T, Guenes S, Gobsch G, Sariciftci NS (2007) Effects of annealing on the nanomorphology and performance of poly (alkylthiophene): fullerene bulk-heterojunction solar cells. Adv Funct Mater 17:1071-1078

20. Gadisa A, Oosterbaan WD, Vandewal K, Bolsée JC, Bertho S, D'Haen J, Lutsen L, Vanderzande D, Manca JV (2009) Effect of alkyl side-chain length on photovoltaic properties of poly (3alkylthiophene)/PCBM bulk heterojunctions. Adv Funct Mater 19:3300-3306

21. Ko S, Verploegen E, Hong S, Mondal R, Hoke ET, Toney MF, McGehee MD, Bao ZN (2011) 3,4-Disubstituted polyalkylthiophenes for high-performance thin-film transistors and photovoltaics. J Am Chem Soc 133:16722-16725

22. Xin H, Kim FS, Jenekhe SA (2008) Highly efficient solar cells based on poly (3-butylthiophene) nanowires. J Am Chem Soc 130:5424-5425

23. Hou JH, Park MH, Zhang SQ, Yao Y, Chen LM, Li JH, Yang Y (2008) Bandgap and molecular energy level control of conjugated polymer photovoltaic materials based on benzo [1,2-b:4,5- $\left.\mathrm{b}^{\prime}\right]$ dithiophene. Macromolecules 41:6012-6018

24. Dou LT, Chang WH, Gao J, Chen CC, You JB, Yang Y (2012) A selenium-substituted low-bandgap polymer with versatile photovoltaic applications. Adv Mater 25:825-831

25. Li XH, Choy WC, Huo LJ, Xie FX, Sha WE, Ding BF, Guo X, Li YF, Hou JH, You JB (2012) Dual plasmonic nanostructures for high performance inverted organic solar cells. Adv Mater 24:3046-3052

26. Zhou HX, Yang LQ, Stuart AC, Price SC, Liu SB, You W (2011) Development of fluorinated benzothiadiazole as a structural unit for a polymer solar cell of 7\% efficiency. Angew Chem Int Ed 123:3051-3054
27. Zhang MJ, Gu Y, Guo X, Liu F, Zhang SQ, Huo LJ, Russell TP, Hou JH (2013) Efficient polymer solar cells based on benzothiadiazole and alkylphenyl substituted benzodithiophene with a power conversion efficiency over 8\%. Adv Mater 25:4944-4949

28. Chen HC, Chen YH, Liu CC, Chien YC, Chou SW, Chou PT (2012) Prominent short-circuit currents of fluorinated quinoxaline-based copolymer solar cells with a power conversion efficiency of $8.0 \%$. Chem Mater 24:4766-4772

29. Liang YY, Xu Z, Xia JB, Tsai ST, Wu Y, Li G, Ray C, Yu LP (2010) For the bright future-bulk heterojunction polymer solar cells with power conversion efficiency of $7.4 \%$. Adv Mater 22:E135-E138

30. Wang XC, Jiang $P$, Chen $Y$, Luo $H$, Zhang ZG, Wang HQ, Li XY, Yu G, Li YF (2013) Thieno [3,2-b] thiophene-bridged D- $\pi$ A polymer semiconductor based on benzo [1,2-b:4,5- $\left.\mathrm{b}^{\prime}\right]$ dithiophene and benzoxadiazole. Macromolecules 46:4805-4812

31. Huo LJ, Zhang SQ, Guo X, Xu F, Li YF, Hou JH (2011) Replacing alkoxy groups with alkylthienyl groups: a feasible approach to improve the properties of photovoltaic polymers. Angew Chem Int Ed 123:9871-9876

32. Dong Y, Hu XW, Duan CH, Liu P, Liu SJ, Lan LY, Chen DC, Ying L, Su SJ, Gong X, Huang F, Cao Y (2013) A series of new medium-bandgap conjugated polymers based on naphtho [1,2c:5,6-c] bis (2-octyl-[1,2,3] triazole) for high-performance polymer solar cells. Adv Mater 25:3683-3688

33. Chang WH, Gao J, Dou LT, Chen CC, Liu YS, Yang Y (2013) Side-chain tunability via triple component random copolymerization for better photovoltaic polymers. Adv Energy Mater 4: DOI:.10.1002/aenm.201300864

34. Yang YC, Wu RM, Wang X, Xu XP, Li ZJ, Li K, Peng Q (2014) Isoindigo fluorination to enhance photovoltaic performance of donoracceptor conjugated copolymers. Chem Commun 50:439-441

35. Li WW, Furlan A, Roelofs WC, Hendriks KH, van Pruissen GW, Wienk MM, Janssen RA (2014) Wide band gap diketopyrrolopyrrole-based conjugated polymers incorporating biphenyl units applied in polymer solar cells. Chem Commun 50:679-681

36. Cabanetos C, El Labban A, Bartelt JA, Douglas JD, Mateker WR, Fréchet JM, McGehee MD, Beaujuge PM (2013) Linear side chains in benzo [1,2-b:4,5- $\left.\mathrm{b}^{\prime}\right]$ dithiophene-thieno [3,4-c] pyrrole4,6-dione polymers direct self-assembly and solar cell performance. J Am Chem Soc 135:4656-4659

37. Lee D, Hubijar E, Kalaw GJD, Ferraris JP (2012) Enhanced and tunable open-circuit voltage using dialkylthio benzo [1,2-b:4,5- $\left.\mathrm{b}^{\prime}\right]$ dithiophene in polymer solar cells. Chem Mater 24:2534-2540

38. Lee JK, Ma WL, Brabec CJ, Yuen J, Moon JS, Kim JY, Lee K, Bazan GC, Heeger AJ (2008) Processing additives for improved efficiency from bulk heterojunction solar cells. J Am Chem Soc 130:3619-3623

39. Peet J, Kim J, Coates NE, Ma WL, Moses D, Heeger AJ, Bazan GC (2007) Efficiency enhancement in low-bandgap polymer solar cells by processing with alkane dithiols. Nat Mater 6:497-500

40. Lu K, Fang J, Zhu XW, Yan H, Li DH, Yang YL, Wei ZX (2013) A facile strategy to enhance the fill factor of ternary blend solar cells by increasing charge carrier mobility. New J Chem 37:1728-1735 